\title{
Effect of Species on Nutritive Value and Methane Production of Citrus Pulps for Ruminants
}

\author{
Çağrı ÖZGÜR ÖZKAN'*, Emrah KAYA², İsmail ÜLGER ${ }^{3}$, \\ İnan GÜVEN ${ }^{2}$, Adem KAMALAK ${ }^{2}$ \\ ${ }^{1}$ Vocational School of Goksun, , Sutcu Imam University, Kahramanmaras, Turkey \\ ${ }^{2}$ Department of Animal Science, Faculty of Agriculture, Sutcu Imam University, Kahramanmaras, Turkey \\ ${ }^{3}$ Department of Animal Science, Seyrani Faculty of Agriculture, University of Erciyes \\ *İletişim (correspondence): e-posta akamalak@ksu.edu.tr; Tel: +90 (344) 2802110 \\ Gönderim tarihi (Received): 11 Nisan 2016; Kabul tarihi (Accepted): 15 Temmuz 2016
}

\begin{abstract}
The experiment was carried out to determine the effect of species on the nutritive value and methane production of citrus pulps. Species had a significant effects $(\mathrm{P}<0.001)$ on the chemical composition, gas production, methane production, metabolisable energy $(\mathrm{ME})$ and organic matter digestibility (OMD) of citrus pulps. Crude protein (CP) content of Citrus paradise was significantly $(\mathrm{P}<0.001)$ higher than those of the other citrus species. Neutral detergent fiber (NDF) and acid detergent fiber (ADF) contents of Citrus sinensis and Citrus reticulata were significantly $(\mathrm{P}<0.001)$ lower than the others. Methane production from Citrus reticulata was significantly $(\mathrm{P}<0.001)$ higher than those of Citrus limon and Citrus paradise. The ME of pulp from Citrus reticulata was significantly $(\mathrm{P}<0.001)$ higher than that of Citrus limon pulp whereas OMD of pulp from Citrus reticulata was significantly $(\mathrm{P}<0.001)$ higher than those of pulps from Citrus limon and Citrus paradise. As conclusion, citrus pulps from different species have a high potential as forage for ruminant animals since citrus pulps have high ME and OMD. However, the CP contents of citrus pulps should be taken into consideration and diets should be fortified with additional CP sources to compensate for the low crude protein when citrus pulps are included into ruminant diets.
\end{abstract}

Keywords: Citrus pulp, nutritive value, metabolisable energy, organic matter digestibility, methane production

\section{Türün Narenciye Posalarının Besin Değerine ve Metan Üretimine Etkisi}

$\ddot{O} \mathbf{z}$

$\mathrm{Bu}$ çalışma, türün narenciye posalarının besin değerine ve metan üretimine etkisini belirlemek için yürütülmüştür. Türün narenciye posalarının kompozisyonu, gaz üretimi, metan üretimi, metabolik enerji içeriği ve organik madde sindirim derecesi üzerinde önemli derecede etkisi vardır. Greyfurt posasının ham protein içeriği diğer narenciye posalarının ham protein içeriğinden önemli derecede yüksektir. Portakal ve mandalina posalarının NDF ve ADF içerikleri diğer posalardan daha düşük bulunmuştur. Mandalina posasının metan üretimi limon ve greyfurt posasının metan üretiminden daha yüksek bulunmuştur. Mandalina posasının metabolik enerji içeriği limon posasının metabolik enerji içeriğinden daha yüksek olasına rağmen mandalina posasının organik madde sindirim derecesi limon ve greyfurt posalarının sindirim derecelerinden daha yüksek bulunmuştur. Sonuç olarak, yüksek enerji ve organik madde sindirim derecesine sahip farklı türlerden elde edilen narenciye posaları kaba yem olarak ruminant hayvanların beslenmesinde önemli bir potansiyele sahiptir. Bununla birlikte narenciye posaları ruminant rasyonlarına katılırken ham protein içeriklerinin göz önüne alınması ve düşük protein içeriğinin telafi edilmesi için rasyonun protein kaynakları ile zenginleştirilmesi gereklidir.

Anahtar Kelimeler: Narenciye posası, besin değeri, metabolik enerji, organik madde sindirim derecesi, metan üretimi

\section{Introduction}

It is well known that feed processing produces considerable amounts of byproducts which are widely used to meet the livestock requirements. The success of integration of byproducts in livestock diets depends on the available information about the chemical composition and nutritive value of byproducts. In Turkey, total citrus fruit production averaged 3480505 tonnes/year from 2008 through 2013 (TUIK, 2014). The citrus fruit such as Citrus sinensis, Citrus limon, Citrus paradise and Citrus reticulata are consumed by humans as fresh fruit and processed juices. Although the considerable amounts of citrus pulp becomes available after extraction of juice, the exact amount of pulps from citrus produced in Turkey is 
not known. Citrus pulps consists of peels, inside portions, seeds and culled fruit which account for approximately 50$65 \%$ of whole fruit, depending on variety of fruit, the processing methods and environmental factors (Ashbell and Donehaye, 1984; Grasser et al., 1995). However fruit from Citrus sinensis accounts for $\% 48.38 \%$ of annual citrus production (TUIK, 2014). About 2-4 \% of fruit from Citrus sinensis is processed into juice (Sancak and Aygoren, 2012). Recently there are considerable amount of citrus pulps productions in Turkey, however the information about nutritive value of pulps from different species is limited.

Due to quick, cheap, less time consuming, the in vitro gas production technique with chemical composition has been used to determine the metabolisable energy and organic matter digestibility of previously uninvestigated feedstuffs (Canbolat, 2012; Guven, 2012; Kamalak et al., 2011; Maheri-Sis et al., 2011; Kaplan et al., 2014; Wencelova et al., 2014). In addition, in vitro gas production technique has been also used to determine the methane reduction potential of feedstuffs (Jayanegara et al., 2009, Jayanegara et al., 2011, Lin et al., 2013, Thang et al., 2012) since enteric methane produced during fermentation is the major contributors to global warming (Lassey, 2007). Recently there are considerable amount of citrus pulps productions and used in ruminant diets to some extent in Turkey, the information about chemical composition and nutritive value of pulps from different citrus species is limited. Therefore the current experiment was carried out to determine the effect of species on the nutritive value and methane production of citrus pulps.

\section{Materials and Methods}

\section{Citrus pulp sample}

The experiment was carried out in University of Kahramanmaras Sutcu Imam, Faculty of Agriculture, and Department of Animal Science. The experimental protocols were approved by the Animal Experimentation Ethics Committee of University of Kahramanmaras Sutcu Imam, Faculty of Agriculture (Protocol No: 2013/ 09-5). Pulps from four different citrus species namely, Citrus sinensis, Citrus limon, Citrus paradise and Citrus reticulata were obtained by using a manual citrus juicer. Pulps samples were dried at $50^{\circ} \mathrm{C}$ and milled in a hammer mill through a $1 \mathrm{~mm}$ sieve for subsequent analysis.

\section{Chemical analysis}

Dry matter (DM) content of citrus pulps was determined by oven drying at $105^{\circ} \mathrm{C} 24$ hours. Ash content was analyzed by igniting the samples of citrus pulps in muffle furnace at $525^{\circ} \mathrm{C}$ for $8 \mathrm{~h}$. Nitrogen $(\mathrm{N})$ content of citrus pulps was determined by the Kjeldahl method (AOAC, 1990). Crude protein of citrus pulps was estimated as N X 6.25. Neutral detergent fiber (NDF) of citrus pulps was analyzed by the method of Van Soest and Wine (1967) and ADF content of citrus pulps were analyzed by the method of Van Soest (1963). All chemical analyses were carried out in triplicate.

\section{Determination of gas and methane production}

Citrus pulps milled through a $1 \mathrm{~mm}$ sieve were incubated in vitro rumen fluid in $100 \mathrm{ml}$ calibrated glass syringes according to the method described by Menke et al. (1979). Rumen fluid was collected from three fistulated Awassi sheep fed twice daily with a diet containing alfalfa hay $(60 \%)$ and concentrate $(40 \%)$ with a free access to water and mineral block. Before mixing the rumen fluid with buffered solution, rumen fluid was filtered through four layers of cheesecloth under flushing with $\mathrm{CO}_{2}$ and combined with buffered solution in the ratio of 1:2, respectively. Approximately 0.200 gram citrus pulp samples were incubated with $30 \mathrm{~mL}$ rumen fluid-buffer mixture in calibrated glass syringes in a water bath at $39^{\circ} \mathrm{C}$. Gas production was determined at 24 $\mathrm{h}$ after incubation and corrected for blank and hay standard (University of Hohenheim, Germany).

$\mathrm{ME}(\mathrm{MJ} / \mathrm{kg} \mathrm{DM})$ content and organic matter digestibility of citrus pulp samples was estimated by the equation described by Menke et al. (1979) as follows:

$M E(M J / k g ~ D M)=2.20+0.136 G P+0.057 C P+0.002859 E E$

$O M D(\%)=14.88+0.889 G P+0.45 C P+0.651 X A$

Where $G P=24$ het gas production $(\mathrm{ml} / 200 \mathrm{mg})$;

$C P=$ Crude protein (\%), EE: Ether extract (\%), XA: ash content $(\%)$.

Methane contents (\%) of total gas produced at $24 \mathrm{~h}$ fermentation of citrus pulps were measured using an infrared methane analyzer (Sensor Europe $\mathrm{GmbH}$, Erkrath, Germany) (Goel et al., 2008). After measuring gas produced at $24 \mathrm{~h}$ incubation, gas samples was transferred into inlet of the infrared methane analyzer using the plastics syringe. The infrared methane analyzer displays methane as percent of total gas. Methane production $(\mathrm{mL})$ was calculated as follows.

Methane production $(m L)=$ Total gas production $(m L) X$ Percentage of Methane (\%) 


\section{Statistical analysis}

One-way analysis of variance (ANOVA) was carried out to determine the effect of species on chemical composition metabolisable energy (ME), organic matter digestibility (OMD) and methane production of citrus pulps. Significance between individual means was identified using the Duncan multiple range test. Mean differences were considered significant at $\mathrm{P}<0.05$. Standard errors of means were calculated from the residual mean square in the analysis of variance.

\section{Results}

The effect of species on the chemical composition on the citrus pulp is given in Table 1. Dry matter content, CP and ash content ranged from 19.24 to $23.90 \%, 6.29$ to $8.51 \%$ and 4.43 to $6.87 \%$, respectively. On the other hand $\mathrm{NDF}, \mathrm{ADF}$ and $\mathrm{EE}$ contents ranged from 17.05 to $23.91 \%, 14.59$ to $20.57 \%$ and 3.51 to $11.44 \%$, respectively. Crude protein of Citrus paradise was significantly $(\mathrm{P}<0.001)$ higher than those of the other citrus species, whereas the ash content of Citrus reticulata was significantly $(\mathrm{P}<0.001)$ higher than those of the other citrus species. NDF and ADF contents of Citrus sinensis and Citrus reticulata were significantly
$(\mathrm{P}<0.001)$ lower than those of Citrus limon and Citrus paradise. On the other hand, EE content of Citrus limon was significantly $(\mathrm{P}<0.001)$ higher than those of Citrus sinensis, Citrus paradisi and Citrus reticulata.

The effect of species on the gas production, methane production, ME and OMD of citrus pulps were given in Table 2. The gas and methane production of citrus pulps at $24 \mathrm{~h}$ incubation ranged from 68.70 to $77.64 \mathrm{ml}$ and 10.15 to $13.62 \mathrm{ml}$, respectively. The gas production of pulp from Citrus reticulata was significantly higher than that of Citrus limon, whereas methane production pulp from Citrus reticulata, was significantly $(\mathrm{P}<0.001)$ higher than those of Citrus limon and Citrus paradise. On the other hand, the percentages of methane from Citrus reticulata and Citrus sinensis were significantly $(\mathrm{P}<0.001)$ higher than those of Citrus limon and Citrus paradise. The ME and OMD of citrus pulps ranged from 12.02 to $13.16 \mathrm{MJ} / \mathrm{kg} \mathrm{DM}$ and 82.72 to $91.53 \%$, respectively. The ME of pulp from Citrus reticulata was significantly $(\mathrm{P}<0.001)$ higher than that pulp from Citrus limon, whereas OMD of pulp from Citrus reticulata was significantly higher than those of pulps from Citrus limon and Citrus paradise.

Table 1. The effect of species on the chemical composition of citrus pulp

\begin{tabular}{|c|c|c|c|c|c|c|}
\hline \multirow{2}{*}{$\begin{array}{c}\text { Nutrients } \\
(\%)\end{array}$} & \multicolumn{4}{|c|}{ Species } & \multirow[b]{2}{*}{ SEM } & \multirow[b]{2}{*}{ Significance } \\
\hline & C.sinensis & C. limon & C.paradisi & C.reticulata & & \\
\hline DM & $23.90^{\mathrm{a}}$ & $19.24^{b}$ & $21.50^{\mathrm{ab}}$ & $21.12^{\mathrm{ab}}$ & 1.402 & $* * *$ \\
\hline $\mathrm{CP}$ & $6.29^{d}$ & $7.86^{\mathrm{b}}$ & $8.51^{\mathrm{a}}$ & $6.99^{c}$ & 0.085 & $* * *$ \\
\hline $\mathrm{CA}$ & $4.43^{\mathrm{b}}$ & $4.96^{\mathrm{b}}$ & $4.80^{\mathrm{b}}$ & $6.87^{\mathrm{a}}$ & 0.336 & $* * *$ \\
\hline $\mathrm{NDF}$ & $17.05^{\mathrm{b}}$ & $21.97^{\mathrm{a}}$ & $23.91^{\mathrm{a}}$ & $17.28^{\mathrm{b}}$ & 0.765 & $* * *$ \\
\hline $\mathrm{ADF}$ & $15.86^{\mathrm{c}}$ & $17.60^{\mathrm{b}}$ & $20.57^{\mathrm{a}}$ & $14.59^{c}$ & 0.468 & $* * *$ \\
\hline $\mathrm{EE}$ & $3.26^{\mathrm{b}}$ & $11.44^{\mathrm{a}}$ & $4.17^{\mathrm{b}}$ & $3.51^{\mathrm{b}}$ & 0.515 & $* * *$ \\
\hline
\end{tabular}

${ }^{a}{ }^{b c}$ Row means with common superscripts do not differ (P>0.05); SEM: standard error mean; DM : Dry matter CP : Crude protein, $\boldsymbol{C A}:$ Crude ash, $\mathbf{N D F}:$ Neutral detergent fiber, $\boldsymbol{A D F}:$ Acid detergent fiber, $\boldsymbol{E E}$ : Ether extract, $* * * P<0.001$

Table 2. The effect of species on the gas production, methane production, metabolisable energy and organic matter digestibility of citrus pulp

\begin{tabular}{|c|c|c|c|c|c|c|}
\hline \multirow[b]{2}{*}{ Parameters } & \multicolumn{4}{|c|}{ Species } & \multirow[b]{2}{*}{ SEM } & \multirow[b]{2}{*}{ Significance } \\
\hline & C.sinensis & C.limon & C.paradisi & C.reticulata & & \\
\hline $\mathrm{TG}(m L)$ & $74.00^{\mathrm{ab}}$ & $68.70^{\mathrm{b}}$ & $71.79^{\mathrm{ab}}$ & $77.64^{\mathrm{a}}$ & 2.154 & $* * *$ \\
\hline $\mathrm{CH}_{4}(m L)$ & $12.55^{\mathrm{ab}}$ & $10.15^{\mathrm{c}}$ & $11.06^{\mathrm{bc}}$ & $13.62^{\mathrm{a}}$ & 0.581 & $* * *$ \\
\hline $\mathrm{CH}_{4}(\%)$ & $16.95^{\mathrm{a}}$ & $15.12^{\mathrm{b}}$ & $15.40^{\mathrm{b}}$ & $17.53^{\mathrm{a}}$ & 0.474 & $* * *$ \\
\hline $\mathrm{ME}$ & $12.63^{\mathrm{ab}}$ & $12.02^{\mathrm{b}}$ & $12.46^{\mathrm{ab}}$ & $13.16^{\mathrm{a}}$ & 0.293 & $* * *$ \\
\hline OMD & $86.38^{\mathrm{ab}}$ & $82.72^{\mathrm{b}}$ & $85.66^{\mathrm{b}}$ & $91.53^{\mathrm{a}}$ & 1.915 & $* * *$ \\
\hline
\end{tabular}

${ }^{a b c}$ Row means with common superscripts do not differ $(P>0.05)$; SEM: Standard error mean;

TG: total gas production(ml), ME :Metabolisable energy MJ /Kg DM, OMD :Organic matter digestibility (\%) *** P<0.001.

\section{Discussion}

As represented in Table 1 the species had a significant effect on the chemical composition of citrus pulp. The CP contents of Citrus sinensis and Citrus limon were consistent with findings of Nazem et al. (2008) who reported that $\mathrm{CP}$ contents of Citrus sinensis and Citrus limon were 6.3 and $6.8 \%$, respectively. The NDF and ADF contents of Citrus limon were consistent with findings of Nazem et al. (2008) who reported that NDF 
and ADF contents of Citrus limon were 21.3 and $17.9 \%$, respectively. However the NDF and ADF contents of Citrus sinensis were considerably lower than those reported by Nazem et al. (2008) who found that the DF and ADF contents of Citrus sinensis were 26.1 and $20.3 \%$, respectively. On the other hand Although NDF and ADF contents of Citrus sinensis and Citrus limon were considerably lower than those reported by Ibrahim et al. (2011), the EE contents of Citrus sinensis and Citrus limon were consistent with findings of Ibrahim et al. (2011). The differences among these studies were possibly associated with differences in variety of citrus, the processing methods and environmental factors.

As can be seen from Table 1, although it seems to be likely that $\mathrm{CP}$ contents of citrus pulp except for Citrus sinensis will meet the $\mathrm{CP}$ requirements of ewes for maintenance, it is unlikely that citrus pulp studied in this experiment will meet the $\mathrm{CP}$ requirement of ewes for lactation, since El-Shatnawi and Mohawesh (2000) reported that ewes require $7-9 \% \mathrm{CP}$ for maintenance and $10-12 \%$ for lactation.

The species had a significant effect on the gas production, methane production, ME and OMD of citrus pulp (Table 2). The OMD values of Citrus sinensis and Citrus limon were considerably higher than those reported by Nazem et al. (2008) who reported that OMD values of Citrus sinensis and Citrus limon were 78.2 and $75.5 \%$, respectively.

As can be seen from Table 2, pulps from Citrus limon and Citrus paradise tends to give the lower gas production and methane production when compared with those of pulps from Citrus sinensis and Citrus reticulata. The reason why Citrus limon and Citrus paradise produced lower gas production is possibly associated with high NDF and ADF contents. As can be seen from Table 1, NDF and ADF contents of pulps from Citrus limon and Citrus paradise were higher than those of pulps from Citrus sinensis and Citrus reticulata. It is well known that there is negative correlation between gas production and NDF or ADF contents (Kamalak et al., 2005a; Kamalak et al., 2005b). In addition, essential oil in Citrus limon and Citrus paradise might have resulted in lower gas and methane production. Therefore essential oil from Citrus limon and Citrus paradise is deserved to be tested for their effect on the gas and methane production.

Lopez et al. (2010) suggested that methane percentage of total gas produced after 24 hour fermentation can be used to determine the methane reduction potential of any feedstuffs and the feedstuffs can be classified in three groups, low potential ( $\%$ methane in gas between $>11 \%$ and $\leq 14 \%$ ), moderate potential ( $\%$ methane in gas between $>6 \%$ and $<11 \%$ ), high potential ( $\%$ methane in gas between $>0 \%$ and $<6 \%$ ). Therefore it seems to be unlikely that citrus pulps studied in the current study had no methane reduction potential since the percentage of methane for citrus pulp is higher than $\% 14$.

\section{Conclusion}

As conclusion, citrus pulps from different species have a high potential as forage for ruminant animals, since citrus pulps have high $\mathrm{ME}$ and OMD. However, the $\mathrm{CP}$ contents of citrus pulps should be taken into consideration and diets should be fortified with additional crude protein sources to compensate for the low crude protein when citrus pulps are included into ruminant diets.

\section{Kaynaklar}

AOAC. 1990. Official method of analysis. Association of official analytical chemists. $15^{\text {th }}$ ed., pp.66-88, Washington, DC, USA.

Ashbell, G., Donehaye, E. 1984. Losses in orange peel silage. Agr. Waste, 11, 73-77.

Canbolat, O. 2012. Potential nutritive value of field bindweed (Convolvulus arvensis L) hay harvested at three different maturity stages. Kafkas Üniv. Vet. Fak. Derg. 18(2), 331-335.

El-Shatnawi, M.K., Mohawesh, Y.M. 2000. Seasonal chemical composition of saltbush in semiarid grassland of Jordan. J Range Manage. 53, 211-214.

Goel, G., Makkar, H.P.S. Becker, K. 2008. Effect of Sesbania sesban and Carduus pycnocephalus leaves and Fenugreek (Trigonella foenum-graecum L) seeds and their extract on partitioning of nutrients from roughage-and concentrate-based feeds to methane. Anim. Feed Sci. Technol. 147(1-3), 72-89.

Grasser, L.A., Fadel, J.G., Garnett, L., DePeters E.J. 1995. Quantity and economic importance of nine selected by products used in California dairy rations. J. Dairy Sci. 78: 962-971.

Guven, I. 2012. Effect of species on nutritive value of mulberry leaves. Kafkas Üniv Vet Fak Derg. 18 (5), 865-869.

Ibrahim, M.R., El-Banna, H.M., Omara, I.I., Suliman, M.A. 2011. Evaluation of nutritive value of some citrus pulp as feedstuffs in rabbit diets. Pak. J. Nutr. 10(7), 667-674. 
Jayanegara, A., Togtokhbayar, N., Makkar, H.P.S., Becker, K. 2009. Tannins determined by various methods as predictors of methane production reduction rumen potential of plants by an in vitro rumen fermentation system. Anim. Feed Sci. Technol. 150(34), 230-237.

Jayanegara, A., Wina, E., Soliva, C.R., Kreuzer, M., Leiber, F. 2011. Dependence of forage quality and methanogenic potential of tropical plants on their phenolic fractions as determined by principal component analysis. Anim. Feed Sci. Technol. 163 (2-4), 231-243.

Kamalak, A., Atalay, A.I., Ozkan, C.O., Kaya, K., Tatliyer, A. 2011. Determination of nutritive value of Trigonella kotschi Fenz hay harvested at three different maturity stages. Kafkas Üniv Vet Fak Derg, 17 (4), 635-640.

Kamalak, A., Canbolat, O., Gurbuz, Y., Erol, A., Ozay, O. 2005. Effect of maturity stage on chemical composition, in vitro and in situ dry matter degradation of tumbleweed hay (Gundelia tournefortii L). Small Rum. Res. 58(2), 149-156.

Kamalak, A., Canbolat, O., Gurbuz, Y, Ozkan, C.O., Kizilsimsek, M. 2005. Determination of nutritive value of wild mustard, Sinapsis arvensis harvested at different maturity stages using in situ and in vitro measurements. Asian-Austral. J. Anim. Sci. 18(9), 1249-1254.

Kaplan, M., Kamalak, A., Kasra, A.A., Guven, I. 2014. Effect of maturity stages on potential nutritive value, methane production and condensed tannin content of Sanguisorba minor hay. Kafkas Üniv Vet Fak Derg, 20 (3), 445-449.

Lassey, K.R. 2007. Livestock methane emissions from the individual grazing animal through national inventories to the global methane cycle. Agr. Forest Meteorol. 142(2-4), 120-132.

Lin, B., Wang, J.H., Lu, Y., Liang, Q., Liu, J.X. 2013. In vitro rumen fermentation and methane production are influenced by active components of essential oils combined with fumarate. J. Anim. Physiol. Anim. Nutr. 97(1), 1-9.

Lopez, S., Makkar, H.P.S., Soliva, C.R. 2010. Screening plants and plant products for methane inhibitors. In:
Vercoe PE, Makkar HPS, Schlink A, (Eds): In vitro screening of plant resources for extra nutritional attributes in ruminants: Nuclear and related methodologies. London, New York, pp. 191-231.

Maheri-Sis, N., Baradaran-Hasanzadeh, A.R., Salamatdoust, R., Khosravifar, R., AgajanzadehGolshani, A., Dolgari-Sharaf, J. 2011. Effect of microwave irradiation on nutritive value of sunflower meal for ruminants using in vitro gas production technique. J. Anim. Plant Sci. 2(12), 126-131.

Menke, K.H., Raab, L., Salewski, A., Steingass, H., Fritz, D., Schneider, W. 1979. The estimation of the digestibility and metabolizable energy content of ruminant feedingstuffs from the gas production when they are incubated with rumen liquor in vitro. J. Agric. Sci. (Camb), 93(1), 217-222.

Nazem, K., Rozbehan, Y., Shodjaosadati, S.A. 2008. The nutritive value of citrus pulp (Lemon and Orange) treated with Neurospora sitophilla. Journal of Scientific and Technological Agriculture and Natural Resources, Water and Soil Science, 12(43), 495-506.

Sancak A.Z., Aygoren, E. (2012): Portakal suyu, TEPGE, 14(1): 1-7.

Thang, C.M., Winding, S., Hang, L.T. 2012. Effects of different foliages and drying methods on mitigation methane production based on cassava root meal using in vitro gas production. J. Anim. Sci.Technol. 34, 4050 .

TUIK. 2014. Bitkisel Üretim İstatistikleri. Türkiye İstatistik Kurumu, http://www.tuik.gov.tr, Erişim tarihi: 15 Mart 2014

Van Soest, P.J. 1963. The use of detergents in the analysis of fibrous feeds. II. A rapid method for the determination of fiber and lignin. J.A.O.A.C. 46, 829-835.

Van Soest, P.J., Wine, R.H. 1967. The use of detergents in the analysis of fibrous feeds. IV. Determination of plant cell wall constituents. J.A.O.A.C. 50, 50-55.

Wencelova, M., Varadyova, K., Mihalikova, D., Jalc, D., Kisidayova, S. 2014. Effects of selected medicinal plants on rumen fermentation in a high-concentrate in vitro. J. Anim. Plant Sci. 24(5):1388-1395. 